\title{
IMPROVING THE PRODUCTIVITY OF BUSINESS MICRO MICROBES IN WARNASARI VILLAGE
}

\author{
Trisa Nur Kania ${ }^{1}$, Dindin Abdurohim ${ }^{2}$, Latifah Adnani ${ }^{3}$, Atin Hafidiah ${ }^{4}$ \\ 1,2,3,4 Universitas Pasundan, Bandung, Indonesia \\ 1trisa.nurkania@unpas.ac.id, 201indin.abdurohim@unpas.ac.id \\ ${ }^{3}$ latifah.adnani@unpas.ac.id, ${ }^{4}$ atinhafidiah@unpas.ac.id
}

\begin{abstract}
The problems faced by PKM Partners are on a number of factors that are difficult to be resolved by Partners, namely relating to production equipment that is worn, does not have a production permit, does not have a brand, has not been tested for product nutrition, has not been packaged with attractive performance. Therefore this activity aims to provide assistance so that the micro-businesses occupied by Partners can be further increased in the number and quality of products they produce. Service activities are carried out in the form of facilitation of production equipment, facilitation of product nutrition testing, financial management training and facilitation of product brand design. The results of the activity can be described that currently Partners: 1. already has the following new equipment Spinner to squeeze oil from freshly fried potato chips, 2. The oil content in the product has been reduced enough to be safe for consumption, 3. The nutritional content of the product is already known because it has been tested in the TP Lab the nutritional content contained in potato chips, 4. Already able to understand about the character of a superior entrepreneur and and will try to become a formidable business actor at the micro business level, 5. Partners are helped to design product brands, namely "Kripang"
\end{abstract}

Keywords: Increased Productivity

\section{A. Introduction}

Micro, small and medium enterprises (MSMEs) in our country have an important role in supporting the national economy because in addition to being a land of employment opportunities for the majority of citizens with relatively low levels of education, MSMEs are also one of the places where various ideas of business actors can be developed through the use of existing resources in our country, both in terms of natural natural resources and human resources. If you look at the natural resources and human resources that are abundant in our country, the opportunity to create various kinds of businesses is very possible. In this case, creativity and innovation are needed to be able to create a business so that people who have creative ideas are needed who are able to create business / business opportunities that will be able to be developed starting from a small scale, medium scale or large scale. Proper management in handling business activities will in turn be very helpful in 
moving the economic wheels of the community. This has the potential to occur because a well-managed business can develop into a mediumsized business or even a large business that can accommodate human resources in accordance with the development and manpower needs of the business. Thus, if something like that can be done by a business actor, then the growth of his business will help solve the labor problem in the place / region concerned.

If you look at the natural resources in our country, especially in the district of Bandung, West Java province, there are quite a lot of natural resources in this region that can be relied on to encourage the movement of the people's economy. One example that can be cited here is the Pangalengan sub-district. Pangalengan sub-district is a highland area in the South Bandung area with cool temperatures and tends to be cold in the early hours. This area had long been an area that was used as commercial plantation land by Dutch colonialists in Indonesia, namely in the mid-18th century. The fertility of the land in the Pangalengan sub-district was not only used as tea plantation land by the colonial government, but also by the local community it became land that was very reliable for growing various types of vegetables, such as: carrots, tomatoes, potatoes, cabbage, chilies and others. There is no doubt about the use of vegetables as a basic food material that is used to be consumed by humans, therefore in relation to efforts to increase the economic value of vegetables, it can be done through creativity and the right ideas. then vegetable food can be further processed so that it can become other types of food that have a selling value / economic value, so that it has the potential to become a lucrative source of income for certain parties who are able to process and manage it in a routine business activity and can be managed properly. good business management. One example of processed food made from vegetables is vegetable chips. Erliza Hambali et al (2007: 5-6) stated that "vegetable chips are one of the processed products of horticultural products. The existence of this product is not new to the people of Indonesia. This is related to the abundant availability of horticultural products in various regions in Indonesia. The development of this 
product is still considered very potential considering the large market opportunities that can be targeted and the emergence of various diversification of vegetable products. Processing of horticultural products into vegetable chips does not require high technology. Therefore, this vegetable chips processing industry can be applied in small industries ".

Warnasari Village, which is one of the villages in Pangalengan subdistrict, has a population that is quite creative in using various natural products to become snack products that are preferred by consumers.

Products that have been produced by community members who are business actors in this area include: potato chips, milk crackers, coffee beans, banana molen, waluh crackers, carrot crackers, eggplant sweets and others. Among these snack products, the author will examine the potato chip products produced by Mrs. Iim Rusmini, where she is a resident of RT 01 RW 15, which has been producing potato chips since 2014. These potato chips are tasty and crunchy, so if someone is already try to eat it, usually will be addictive because it tastes good. However, it is unfortunate that the potato chip business is still very small in scale and has only been marketed in the area around Mrs. Iim's residence. Even though if this business is developed using professional business management, there will be a very good chance to become one of the typical Pangalengan souvenir products like other snacks that have been known in advance by the wider community as typical souvenirs from the Pangalengan sub-district, such as : caramel milk candy, milk lunkhead, milk crackers and others. Regarding the condition of Mrs. Iim's potato chip business, we as the implementation team for the PKM FISIP Unpas activities will describe the conditions of the micro-businesses occupied by business actors so that we can find out more about what efforts the PKM implementation team can do related to community service activities. community that will be carried out at this PKM Partners place.

Partner Potato Chips Business Conditions : This potato chip micro business was started in 2014, when a vegetable tycoon in Warnasari village gave a sack of Atlantic potato to Mrs. Iim. After thinking for a while, Mrs. Iim took the initiative to process the potatoes into potato chips. The trial was 
conducted several times, until finally Mrs. Iim found the right way to make the potato chips into delicious and crunchy chips. It should be stated here that Mrs. Iim has worked for 5 years in a catering company in the local village area, so she has a fairly good knowledge in terms of processing food ingredients. The potato chips go on sale at retail at a price of $\mathrm{Rp} .40,000$ per $1 / 2$ kg. After that $\mathrm{Bu}$ Iim's potato chips became known by the people around her house. Until now, Mrs. Iim is still actively producing potato chips although the quantity is still limited because she can only process $5 \mathrm{~kg}$ of raw potato for one production period.

The following are the business aspects related to Mitra's potato chip business: The raw material used by Mitra is Atlantic potato, which is a type of potato specifically used for processing into chips because it produces a crispy potato taste.

Production equipment uses simple tools that are usually in the kitchen as common cooking utensils. Some of the utensils needed are a stove, frying pan and spatula, basin, knife, cutting board, strainer, pestle. Production capacity, the amount of product in one production is about $5 \mathrm{~kg}$ of raw potatoes. In addition, there are additional supporting ingredients for spices such as salt and flavorings so that the potatoes taste delicious and delicious on the taste of consumers. Based on the results of observations from the Business Administration Study Program student fieldwork which was held in July 2019, it can be seen that the potato chip production equipment is in worn condition so it should be replaced with new cooking utensils. In addition, the production tools for making potato chips still use Mrs. Iim's personal kitchen utensil, so it can be said that the use of equipment is mixed between the need for cooking with the need for potato chips production. Meanwhile, regarding the costs required by Partners for each production period, it is usually around Rp. 80,000 where the source of the cost is personal expenses which are the Partner's savings.

\section{Partnership's Potato Chips}

Business Management is carried out simply personally by the Partner, which includes matters of purchasing raw materials and other additives, production processes and in financial matters. This is more due to the fact that the Partner is solely taking care of 
everything related to this potato chip micro business. Thus the human resources in this PKM Partner are only Partners themselves. Potato chips marketing still conducted in the vicinity of Mitra's residence.

Financially, the funds used for the Partner's business come from his personal money, because the amount needed is deemed sufficient to purchase the ingredients needed for the manufacture of potato chips. Chips packaging, only using ordinary clear plastic and wax which is used to close the plastic wrapping cover. Based on the explanation previously described, it can be seen that the partner potato chip micro business requires efforts to increase the quantity and quality of the product, which is related to the following factors: Production equipment that has been used by Partners already needs to be updated immediately because it is wearing out, and the production equipment for making chips is still mixed with tools used for kitchen / cooking purposes in Partner's household kitchens. Equipment needs include: gas stove + hose + regulator, grater, knife, cutting board, bucket, scoop, scale, spinner.
The potato chip packaging needs to be displayed in a more attractive and branded performance so that it can be distinguished from other similar products.

A permit is required for the food products industry produced by households / IPRT from the health office to ensure the suitability of food for human consumption.

Potato chip products will be even more convincing for people who will consume them if the product is certified as an acknowledgment of a halal product from the Indonesian Ulema Council, considering that residents around Bandung Regency or West Java are predominantly Muslim.

Partner's financial management in this business is still in the form of pocket management, so Partners need an understanding of more orderly financial management and management.

The marketing of potato chips products is still limited around the village, so there needs to be certain efforts to expand the product marketing area.

The quality of potato chip products needs to be tested by the authorized institution in terms of food 
product safety, especially in terms of the nutritional composition in the product and in terms of the time span for use / consumption, so that consumers will receive nutritional information and product expiration period through writing that can be inserted informed in the packaging which is varied in the writing of the potato chip product brand.

With regard to product brands, it will provide more confidence to business actors, if the potato chip product brand is officially registered with the DITJEN HAKI, West Java province.

The business conditions of Partners that are running in moderation illustrate the conditions experienced by many micro and small business actors as stated by Leiwakabessy, et al, who stated that various problems are still found, the most fundamental in this case is related to the low productivity of MSMEs. The low productivity is presumably due to the low quality of the human resources of MSMEs, especially in the fields of management, mastery of technology and marketing. (Kutipan mendeley).

More specifically, when viewed from a review that looks at the conditions of MSMEs in Bandung district, it is clear that the Baseline Assessment that has been carried out by the Lecturer team on several small business actors in Bandung Regency illustrates that the problems faced by these business actors are quite diverse. Starting from the problems of capital, marketing, productivity and innovation. This was also conveyed by Mr. Usman Karyana as the Head of the Development and Development Division of the Bandung Regency Office of Cooperatives and UKM, that currently SMEs are still constrained in terms of access to capital financing, the ability to innovate and product marketing. These three things are closely related to productivity issues (Kutipan mendeley)

Therefore, the implementation of this service activity is an effort to increase the productivity of the Partner's micro business because this PKM Partner faces many obstacles that are difficult to solve by the Partner due to the limitations that the Partner has as previously explained. Related to the use of the term productivity here, the implementation team refers to the explanation of Buchari Alma (2016: 85) which states that "Productivity is 
the quantity or volume of products or services produced. However, many views state that productivity is not only the quantity, but also the quality of the products produced, which should also be used as a consideration to measure the level of productivity".

In connection with the definition of productivity, in the discussion of this service activity report, the term productivity associated with Team activities is productivity in terms of improving the quality of products produced by Partners, because the efforts made by the Implementing Team include testing the oil content and nutritional testing. products that the Partner has not done since the Partner started the business of producing potato chips.

\section{B. Method of Implementation}

The approach method used in partner service activities is:

a. Facilitate the procurement of production equipment

b. Facilitating product nutrition testing and testing of fat content in potato chips, at the Pasundan University Food Laboratory.

c. Counseling and training on small business financial management d. Facilitate product branding

\section{Result and Discussion}

The service carried out at the Partner consists of several stages of activities in accordance with the conditions of the Partner and the conditions of the Implementing Team, which are as follows:

a. Activity preparation

1. Compiling proposals and coordinating with the team in the activity implementation group to discuss the need for division of tasks that must be carried out by team members, namely: surveys of business actors who will become partners, compiling proposals and setting priorities for assistance to be carried out to Partners.

2. Carry out coordination meetings with the implementing team. At this stage, the implementation team arranges the activity plan to be carried out according to known problems so that the stages can be carried out according to the predetermined plan, up to the preparation of the final report and articles that will be published in journals that have been previously targeted. 
3. Preparing business actors to receive planned service activities.

4. Develop a schedule of activities to be carried out in the field.

b. Implementation of Activities

The implementation of activities is expected to be carried out in two funding periods because it is adjusted to the needs of Partners. In this case, in connection with the financing that has been obtained from the party giving the activity funds, the activities in the first year can be carried out through the following stages:

1. The first stage is to explore the data on needs disclosed by Partners in relation to the items needed to produce potato chips, namely production equipment and complementary measures for product packaging, including: katel, scoop, spatula, knife, potato grater, gas stove + regulator + hose, small scale.

2. The second stage is to facilitate the nutritional test of potato chips by bringing a sample of potato chip products which will be checked at the UNPAS Food Technology Lab to find out the composition of the ingredients used in the potato chips as well as the nutritional composition of the product and the content of the product. fat in potato chip products. This is also done in order to determine the safety of food ingredients used in potato chip products by Partners.

3. The third stage is the purchase of production equipment in accordance with the conditions stated by the Partner, during the survey.

4. The fourth stage is carrying out activities in the field, namely delivering the production equipment needed by Partners for the manufacture of potato chip products

5. The fifth stage provides counseling and training on simple financial management to Partners. Extension is an effort to provide information to help someone find their way (Wikipedia, 2019) Meanwhile, what is meant by training according to Suwatno and Donni is an effort to increase a person's knowledge and skills to implement certain work activities (2014: 117), where efforts to increase knowledge can realize the goals to be achieved. In this case, the goal to be achieved is to increase Partner's knowledge related to financial management and record it in a simple financial report in 
accordance with Partner's ability to manage his potato chip business.

6. The 6th stage was facilitated with the making of the KRIPANG potato chip brand design

In this service activity Partners can participate actively, among others, through enthusiasm for accepting the implementation team and will strive to increase the amount of production in order to show business performance that is increasing in quantity and in product quality. In addition, Partners are also very helpful in providing their time and energy to receive counseling delivered by the implementation team regarding activities and materials provided to Partners. In this case, the implementation team sees and observes that Partners can accept all activities carried out, so this is clearly very helpful for the smooth implementation of PKM activities. Therefore, it can be explained here that the Partner's business conditions after the implementation of PKM activities are as follows:

a. Partners can use production equipment specifically for the business of making potato chips so that it is hoped that it can increase the amount of production and use of this equipment does not mix with Partner's kitchen equipment.

b. Partners can improve product quality in terms of reducing oil content through a spinner as an aid in minimizing the oil content in fried potato chips, where after going through the spinner process, potato chips look drier and more crunchy and do not leave cooking oil droplets in in plastic packaging.

c. Partners can find out the nutritional composition contained in the potato chips they produce because facilitation of potato chip product nutrition tests has been carried out in the Food Engineering Laboratory of Pasundan University.

d. Partners can arrange and sort out the business money and household money because Partners have been provided with education about simple financial management for their potato chip business.

e. Mitra's potato chip product has a brand because it has facilitated the design of Mrs. Iim's potato chip brand, namely the "KRIPANG" brand. 


\section{Conclusion}

PKM activities that have been carried out by the Implementing Team for Partners have been successfully implemented according to plan, because Partners are very enthusiastic and welcome the service activities carried out by the Implementing Team. The stages of activities carried out can run smoothly and the Partner can also understand the counseling that has been carried out on financial management to Partners. Thus in the first year PKM activities can be carried out according to the implementation team's plan. Suggestions that can be conveyed to the institution are that this PKM activity should be able to be continued in the second year, in connection with several activities that are still needed by Partners from the Implementing Team so that this PKM activity can really help raise the class of Partners' micro businesses into businesses. small ones who are able to produce snacks with tastes that are liked by the community and contain nutrients that are beneficial to human health, have a brand and have a halal logo, use attractive packaging, and can become typical souvenir products from Warnasari village, Pangalengan district.

\section{REFERENCES}

Buchari Alma, 2016, Kewirausahaan, Cet XXI, Bandung : Alfabeta.

Erliza Hambali, dkk, 2007, Membuat Keripik Sayur,Cet II, Jakarta : Penebar Swadaya

Leiwakabessy, P., Fensca, D., \& Lahallo, F. (2018). pembiayaan usaha mikro kecil dan menengah (umkm) sebagai solusi dalam meningkatkan produktivitas usaha pada umkm kabupaten sorong. Journal of Dedication to Papua Community) (Vol. 1).

Oleh, D. (n.d.). Peningkatan Produktivitas Melalui Program IloScore (Sustaining Competitive And Responsible Enterprises) Bagi Usaha Kecil Dan Program IloScore Plus Bagi Usaha Mikro Yang Tergabung Dalam Paguyuban Pengusaha Usaha Kecil Dan Menengah (Ppkm) Kabupaten Bandung-Jawa Barat.

Septrian Gumilang, dkk, 2019, Keripik Kentang Ibu Iim, Laporan Kuliah Kerja Lapangan, Jurusan Administrasi Bisnis, FISIP Universitas Pasundan.

Suwatno \& Donni Juni Priansa, 2014, Manajemen SDM Dalam Organisasi Publik dan Bisnis, Bandung: Alfabeta 